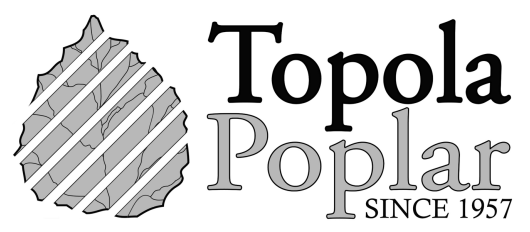

OPEN ACCESS

DOI: $10.5937 /$ topola2108039S

UDC: $630 * 9: 551.583$

Review paper

\title{
Climate change within Serbian forests: current state and future perspectives
}

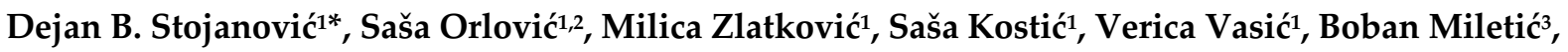

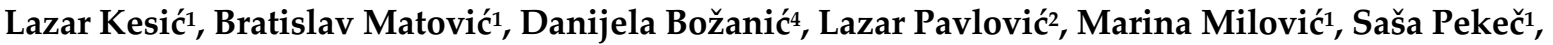 \\ Vladimir Đurđevićs \\ 1 University of Novi Sad, Institute of Lowland Forestry and Environment, Novi Sad, Serbia \\ 2 University of Novi Sad, Faculty of Agriculture, Novi Sad, Serbia \\ 3 University of East Sarajevo, Faculty of Agriculture, Istočno Sarajevo, Republic of Srpska, Bosnia and \\ Herzegovina \\ 4 Climate change expert, Belgrade, Serbia \\ 5 University of Belgrade, Faculty of Physics, Belgrade, Serbia \\ * Corresponding author: Dejan B. Stojanović; E-mail: dejan.stojanovic@uns.ac.rs
}

Received: 16 Nov 2021; Revised: 24 Nov 2021; Accepted: 1 Dec 2021

\begin{abstract}
Extreme weather conditions, namely droughts, heat waves, heavy rains, floods, and landslides are becoming more frequent globally and in Serbia as a result of climate change. Generally, various parts of human society are affected by changing climate conditions. Forest ecosystems are one of the most sensitive systems to weather and climate. In that sense, small changes may lead to large disturbances including forest decline, outbreaks of insect pests and diseases and eventually mortality. In Serbia, the average temperature in forest ecosystems of the most important and abundant forest tree species has risen for more than $1^{\circ} \mathrm{C}$ in the last thirty years (1990-2019) in comparison to the previous period (1961-1990). During the last thirty years, the northern and western parts of Serbia experienced an increase in precipitation as opposed to the southern and eastern parts of the country. If one takes a closer look at the climate within a particular forest stands, it would seem that the effect of precipitation decrease is stronger in less humid parts of a tree species range. In this paper, we discuss various aspects of climate change impacts on forests and forestry, including forest ecology, genetics, physiology, pests and diseases, ground vegetation, monitoring, reporting and verification system, climate change litigation and perspectives of forests in the $21^{\text {st }}$ century in Serbia.
\end{abstract}

Keywords: Pedunculate oak, Sessile oak, European beech, Norway spruce, Silver fir, Scots pine.

\section{Introduction}

At a global level question of climate change has been raised for the first time at the Earth Summit (United Nations Conference on Environment and Development - UNCED) in Rio de Janeiro in 1992. Moreover, at the same Summit an agreement on the Climate Change Convention (United Nations Framework Convention on Climate Change - UNFCCC) was made for the first time and it was followed by Kyoto Protocol and the Paris Agreement. Burning of fossil fuels that needed millions of years to be formed has happened in decades. Kelling Curve, or the graph which represents accumulation of carbon 
dioxide in the Earth's atmosphere measured at Mauna Loa Observatory suited on the island of Hawaii, provides a clear picture of the dramatic increase. Since 1958, levels of carbon dioxide which was continually emitted from world transport, electricity production, industry and other sources have raised in the atmosphere from 313 to 415 parts per million (ppm), which is an increase of $33 \%$ (NOAA, 2021). Consequentially, the greenhouse effect, which is dependent on the concentration of carbon dioxide, and other greenhouse gasses (methane, nitrous oxide, and fluorinated gases) become more and more obvious. Without carbon dioxide in the Earth's atmosphere, surface temperature would be about thirty-three degrees lower than today (NASA, 2021).

Sixth Assessment Report of the Intergovernmental Panel (2021) on Climate Change (IPCC) suggested for the current state that "It is unequivocal that human influence has warmed the atmosphere, ocean and land. Widespread and rapid changes in the atmosphere, ocean, cryosphere, and biosphere have occurred", and also suggested that "Global surface temperature will continue to increase until at least the mid-century under all emissions scenarios considered. Global warming of $1.5^{\circ} \mathrm{C}$ and $2^{\circ} \mathrm{C}$ will be exceeded during the $21^{\text {st }}$ century unless deep reductions in carbon dioxide $\left(\mathrm{CO}_{2}\right)$ and other greenhouse gas emissions occur in the coming decades ", as well as that "Many changes due to past and future greenhouse gas emissions are irreversible for centuries to millennia, especially changes in the ocean, ice sheets and global sea level." (IPCC, 2021).

Serbia recently adopted the Climate Change Law (Zakon o klimatskim promenama, 2021), which aims to reduce the greenhouse gases emissions that are considered the main reason of climate change. In that sense forestry is at the same time one of the most affected industries that seeks for measures to adapt to climate change, but it is also part of the climate change solution through carbon sequestration. In Serbia, several research projects have dealt with complex climate change issues such as forest ecosystems, including the most prominent project "Studying climate change and its influence on the environment: impacts, adaptation and mitigation (CLENIAM - III43007)" independently financed by the Ministry of Education and Science of the Republic of Serbia within the framework of integrated and interdisciplinary research for the period 2011-2020.

The aims of this paper were to: i) provide an overview of recently observed changed climate conditions within a specific forest ecosystem and ii) present wider context of climate change implications to forestry at the level of the Republic of Serbia.

\section{Material and methods}

Climate data (temperatures and precipitation) were taken from the E-OBS v21.0 (Cornes et al. 2018) network database for the reference (1990-2019) and previous (1961-1990) climate normal, while the spatial distribution of forest tree species in the Republic of Serbia was taken from the First National Forest Inventory of the Republic of Serbia (Banković et al. 2009). The data were proceed using R Studio ( $\mathrm{R}$ Core Team, 2020) and the base packages ( $\mathrm{R}$ Core Team, 2020), ncdf4 (Pierce, 2019) and raster (Hijmans, 2020). The function extract from the R package raster (Hijmans, 2020) was used to calculate the minimum, maximum, average value, and standard deviation of the sum of annual precipitation and average annual temperature for the area of all analysed tree species (excluding Kosovo and Metohija) in reference and previous climatic normal. We also analysed climate conditions within nine forest stand types in Serbia, namely Silver fir (Abies alba Mill.), Norway spruce (Picea abies (L.) H. Karst.), Black and Scots pine (Pinus nigra J.F.Arnold and P. sylvestris L.), European beech (Fagus sylvatica L.), Turkey oak (Quercus cerris L.), Pedunculate oak (Quercus robur L.), Sessile oak (Quercus petraea (Matt.) Liebl.), Hungarian oak (Quercus frainetto Ten.) and Narrow-leaved ash (Fraxinus angustifolia Vahl).

\section{Results}

Results of this study have shown an increase in precipitation in the western part of Serbia, predominantly in areas with higher altitude, which are mostly inhabited by species that require more moisture for their development, such as fir and spruce, and even European beech (Figure 1 and Table 
3). The increase in the amount of precipitation was also observed in the lowland area of Vojvodina, with the largest increase in the areas inhabited by Pedunculate oak $(>20 \mathrm{~mm})$. Moreover, there was a medium increase in precipitation $(>10 \mathrm{~mm})$ in areas inhabited by pines, beech and Turkey oak. The least, practically insignificant, increase in the amount of precipitation was recorded in the areas inhabited by sessile oak, Hungarian oak and narrow-leaved ash. It is extremely important to emphasize that eastern, and south-western part of Serbia were exposed to a decrease in the amount of precipitation, while in central Serbia the situation remained unchanged. It is noticeable that with widespread species (European beech, Turkey oak, sessile oak, Hungarian oak, and pines), the minimal amounts of precipitation within the growing area were lower in 1990-2019 compared to the period of 1961-1990. Areas with maximum rainfall within the species distribution range increased significantly, leading to larger contrast between more arid and more humid parts of the range of the same species.

Considering temperature differences, temperature increases were uniform, ranging from 1.06 to $1.12^{\circ} \mathrm{C}$. However, the largest differences within this range were observed in areas with climazonal (beech, fir and spruce) and azonal vegetation (narrow-leaved ash and pedunculate oak). In the context of the analyzed species, the smallest temperature changes were recorded in the areas inhabited by oaks and pines (Figure 2). Regardless of the species distribution within minimum, medium or maximum temperatures, the increases were almost equal, with the largest changes observed at the minimum temperatures in the case of fir and spruce. Regarding the entire territory of Serbia, the largest temperature increases were noticeable in the easter part of the country, followed by the central part of Vojvodina, and west of Serbia. Overall, oaks and field ash were most exposed to the aridification process, because of a significant temperature increase which was not accompanied by enough precipitation, as in the case of fir and spruce, and even pedunculate oak. The best example of such changes is the eastern part of Serbia, where the extreme increase in temperature was accompanied by a significant decrease in precipitation.

$\Delta 1990-2019 / 1961-1990$
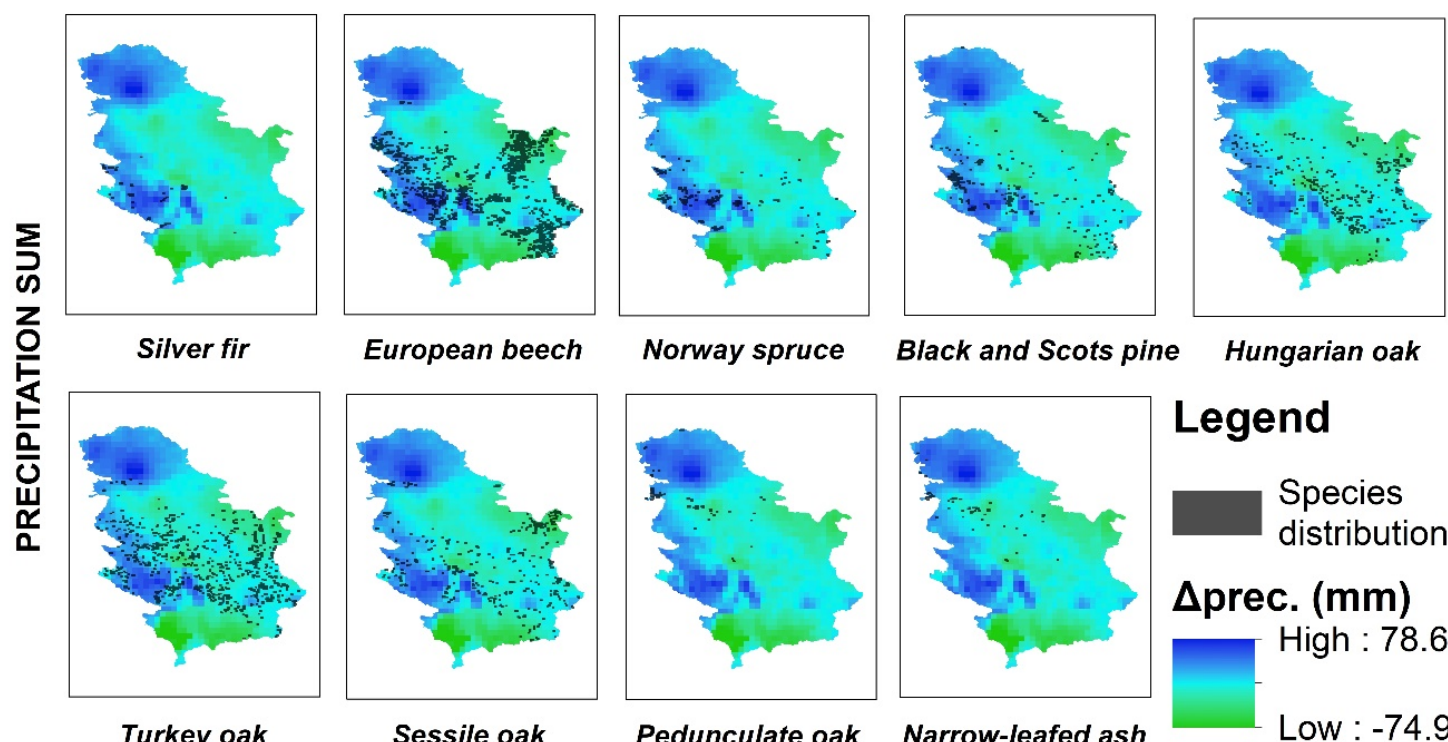

Norway spruce

Black and Scots pine

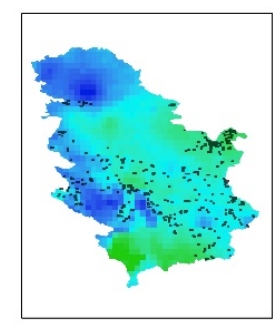

Sessile oak

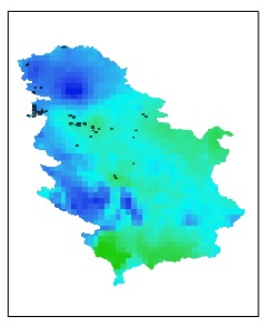

Pedunculate oak

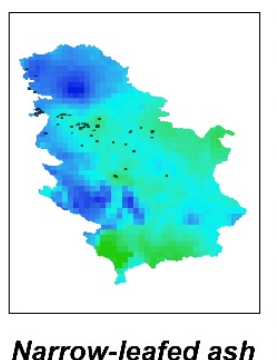

\section{Legend}

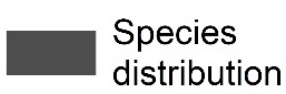

\section{$\Delta$ prec. $(\mathbf{m m})$}

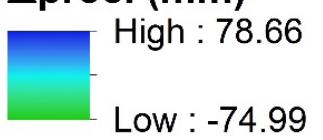

Figure 1. Change of average annual precipitation sum between 1961-1990 and 1990 and 2019 periods. 


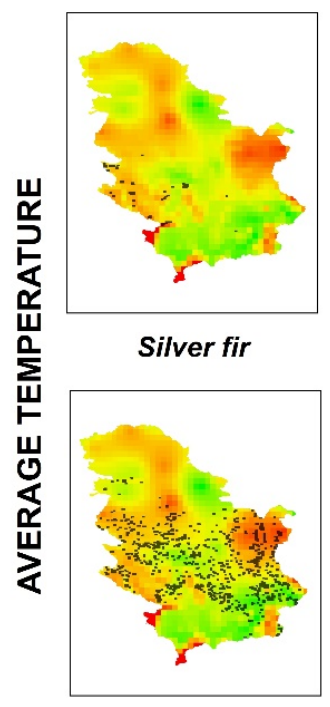

Turkey oak

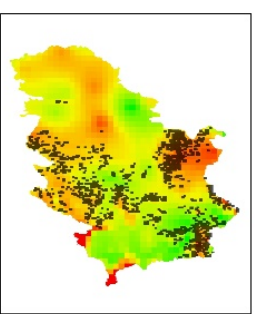

European beech

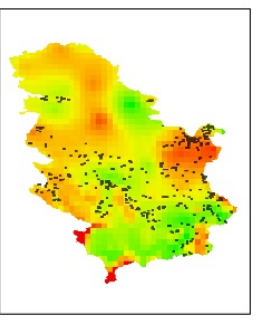

Sessile oak

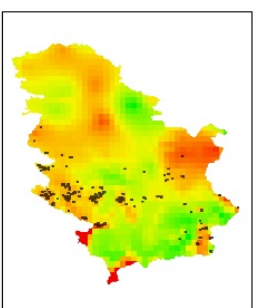

Norway spruce

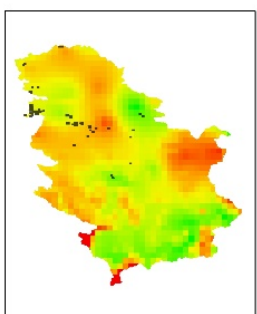

Pedunculate oak

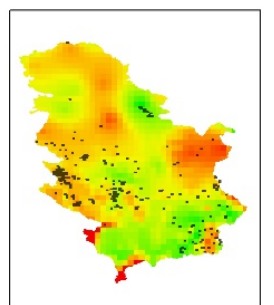

Black and Scots pine

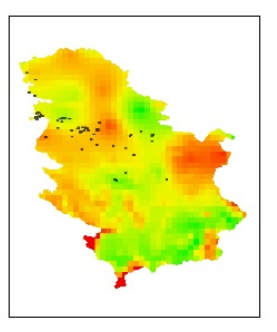

Narrow-leafed ash

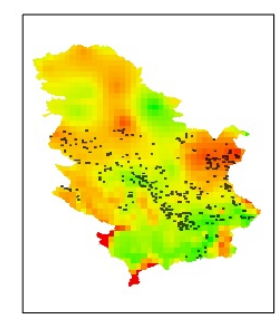

Hungarian oak

\section{Legend}

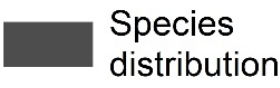

$\Delta$ temp. $\left({ }^{0} \mathrm{C}\right)$

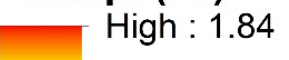

Low : 0.71

Figure 2. Change of average annual temperature between 1961-1990 and 1990 and 2019 periods.

Table 1. Observed average annual sum of precipitation and average annual temperature within stands of the nine most abundant tree species in Serbia for the period 1961-1990.

\begin{tabular}{lcccccccc}
\hline \multirow{1}{*}{\multicolumn{1}{c}{ Stand type }} & \multicolumn{9}{c}{$\mathbf{1 9 6 1 - 1 9 9 0}$} \\
\cline { 2 - 9 } & \multicolumn{2}{c}{ MEAN } & \multicolumn{1}{c}{ MIN } & \multicolumn{2}{c}{ MAX } & \multicolumn{2}{c}{ SD } \\
\cline { 2 - 9 } & $\mathbf{m m}$ & ${ }^{\circ} \mathbf{C}$ & $\mathbf{~ m m}$ & ${ }^{\circ} \mathbf{C}$ & $\mathbf{~ m m}$ & ${ }^{\circ} \mathbf{C}$ & $\mathbf{~ m m}$ & ${ }^{\circ} \mathbf{C}$ \\
\hline Silver fir & 830.76 & 6.99 & 756.11 & 3.94 & 908.72 & 9.70 & 47.99 & 1.51 \\
Norway spruce & 783.05 & 6.79 & 608.03 & 4.26 & 892.11 & 10.69 & 80.58 & 1.69 \\
Black and Scots pine & 723.58 & 8.04 & 594.66 & 5.46 & 885.74 & 10.87 & 83.58 & 1.42 \\
European beech & 708.05 & 7.94 & 596.90 & 4.26 & 891.50 & 11.08 & 72.96 & 1.49 \\
Turkey oak & 686.07 & 9.07 & 572.93 & 5.98 & 869.81 & 11.08 & 76.69 & 1.21 \\
Sessile oak & 670.47 & 8.82 & 596.16 & 5.59 & 875.51 & 11.13 & 64.31 & 1.18 \\
Hungarian oak & 670.04 & 9.54 & 583.31 & 7.73 & 827.86 & 10.97 & 71.74 & 0.78 \\
Narrow-leaved ash & 655.94 & 11.06 & 621.53 & 10.59 & 738.75 & 11.39 & 42.17 & 0.29 \\
Pedunculate oak & 610.41 & 10.99 & 500.03 & 10.50 & 649.58 & 11.39 & 43.60 & 0.27 \\
\hline
\end{tabular}

Table 2. Observed average annual sum of precipitation and average annual temperature within stands of the nine most abundant tree species in Serbia for the period 1990-2019.

\begin{tabular}{lcccccccc}
\hline \multirow{2}{*}{\multicolumn{1}{c}{ Stand type }} & \multicolumn{9}{c}{$\mathbf{1 9 9 0 - 2 0 1 9}$} \\
\cline { 2 - 9 } & \multicolumn{2}{c}{ MEAN } & \multicolumn{1}{c}{ MIN } & \multicolumn{2}{c}{ MAX } & \multicolumn{2}{c}{ SD } \\
\cline { 2 - 9 } & $\mathbf{m m}$ & ${ }^{\circ} \mathbf{C}$ & $\mathbf{~ m m}$ & ${ }^{\circ} \mathbf{C}$ & $\mathbf{m m}$ & ${ }^{\circ} \mathbf{C}$ & $\mathbf{~ m m}$ & ${ }^{\circ} \mathbf{C}$ \\
\hline Silver fir & 867.72 & 8.11 & 776.11 & 5.22 & 949.18 & 10.77 & 53.52 & 1.45 \\
Norway spruce & 817.87 & 7.91 & 621.75 & 5.52 & 931.48 & 11.85 & 92.71 & 1.65 \\
Black and Scots pine & 741.54 & 9.11 & 566.16 & 6.59 & 930.14 & 12.00 & 99.24 & 1.38 \\
European beech & 722.23 & 9.03 & 594.62 & 5.52 & 931.48 & 12.18 & 85.77 & 1.47 \\
Turkey oak & 698.38 & 10.13 & 578.25 & 7.11 & 882.91 & 12.20 & 84.07 & 1.20 \\
Sessile oak & 678.13 & 9.87 & 585.54 & 6.77 & 914.59 & 12.13 & 73.41 & 1.19 \\
Hungarian oak & 677.96 & 10.60 & 566.93 & 8.86 & 858.14 & 12.12 & 77.67 & 0.79 \\
Narrow-leaved ash & 665.77 & 12.16 & 624.32 & 11.73 & 751.22 & 12.50 & 45.09 & 0.29 \\
Pedunculate oak & 632.20 & 12.08 & 532.94 & 11.64 & 679.00 & 12.50 & 41.08 & 0.28 \\
\hline
\end{tabular}


Table 3. Observed change of average annual sum of precipitation and average annual temperature within stands of the nine most abundant tree species in Serbia between periods 1961-1990 and 19902019.

\begin{tabular}{lcccccccc}
\hline \multirow{1}{*}{\multicolumn{1}{c}{ Stand type }} & \multicolumn{9}{c}{$\Delta \mathbf{1 9 9 0 - 2 0 1 9 - 1 9 6 1 - 1 9 9 0}$} \\
\cline { 2 - 10 } & \multicolumn{2}{c}{ MEAN } & \multicolumn{1}{c}{ MIN } & \multicolumn{2}{c}{ MAX } & \multicolumn{2}{c}{ SD } \\
\cline { 2 - 10 } & $\mathbf{m m}$ & ${ }^{\circ} \mathbf{C}$ & $\mathbf{m m}$ & ${ }^{\circ} \mathbf{C}$ & $\mathbf{m m}$ & ${ }^{\circ} \mathbf{C}$ & $\mathbf{m m}$ & ${ }^{\circ} \mathbf{C}$ \\
\hline Silver fir & 36.96 & 1.12 & 20.00 & 1.28 & 40.46 & 1.07 & 5.53 & -0.06 \\
Norway spruce & 34.82 & 1.12 & 13.72 & 1.26 & 39.37 & 1.16 & 12.13 & -0.04 \\
Black and Scots pine & 17.96 & 1.07 & -28.50 & 1.13 & 44.40 & 1.13 & 15.66 & -0.04 \\
European beech & 14.18 & 1.09 & -2.28 & 1.26 & 39.98 & 1.10 & 12.81 & -0.02 \\
Turkey oak & 12.31 & 1.06 & 5.32 & 1.13 & 13.10 & 1.12 & 7.38 & -0.01 \\
Sessile oak & 7.66 & 1.05 & -10.62 & 1.18 & 39.08 & 1.00 & 9.1 & 0.01 \\
Hungarian oak & 7.92 & 1.06 & -16.38 & 1.13 & 30.28 & 1.15 & 5.93 & 0.01 \\
Narrow-leaved ash & 9.83 & 1.10 & 2.79 & 1.14 & 12.47 & 1.11 & 2.92 & 0.00 \\
Pedunculate oak & 21.79 & 1.09 & 32.91 & 1.14 & 29.42 & 1.11 & -2.52 & 0.01 \\
\hline
\end{tabular}

\section{Discussion}

\subsection{Forest ecology and growth}

Trees are highly sensitive to intensive climate changes. Their cambial activity is limited via surrounding stands as well as climate conditions. A lot of radial growth drivers are revealed, and their effects are different and synergic on tree-ring properties such as their increment, stable isotope ratio (Kostić et al. 2019), xenobiotic, and metabolism-related products (Wang et al. 2021). In a temperate climate, major tree species such as European beach (Fagus sylvatica L.; Stjepanović et al. 2018), Norway spruce (Picea abies (L.) H. Karst.; Matović et al. 2018), pine (Pinus sylvestris L.; Pretzsch et al. 2015), and pedunculate oak (Quercus robur L.; Stojanović et al. 2015, 2018; Kostić et al. 2019, 2021a, 2021b, 2021c) are recognized as a climate-sensitive species to a lot of surrounded environmental factors.

Published studies related to tree-ring properties noted that all above-mentioned species are highly sensitive to unfavorable extreme climate events such as warming, drought, river water level decreasing, etc. Stojanović et al. (2015) showed that river water level decreasing significantly reduces all, young and two-century-old pedunculate oak specimens in riparian flooded Danube's forests in Vojvodina province, the north and lowland part of the Republic of Serbia. Drought also affects radial growth. In a comparable study among pine, beach and oak Stojanović et al. (2018) detected long-term effect of drought indices on radial growth, up to three years. In both papers, temperature and precipitation are labelled as significant climate factors to radial increment. Matović et al. (2018) found that extremely high temperatures in the growing period in three related years $(2011,2012$ and 2013) in conjunction with extremely low rainfall in 2012 were the primary cause of declining thickness growth, devitalization and mortality of spruce trees at National Park "Kopaonik".

Stand conditions, such as soil properties, changed tree drought sensitiveness (Kostić et al. 2021a). Authors observed that oaks from different soil types vary in sensitiveness to surrounding climate conditions. In detail, oaks from more suitable soils to oak growing with higher underground water had greater radial growth and lower sensitiveness to drought and other negative climate events. In the regional oak study, Kostić et al. (2021c) showed that soil water is a significant radial growth drive as same as commonly used climate factors such as temperature, precipitation, and drought indices. Also, the same study showed that oak from the moderately wet stands had an ambiguous radial growth and the lowest oscillation compared with oaks from drier and wetter oak' stands.

In Serbia, two pedunculate oak proveniences were isolated (Banković et al. 2009). Serbia has long tradition in forest management of oak forests (Rađelović et al. 2020). The published paper showed that pedunculate oak is a highly variable species (Kesić et al. 2021). Also, their variability in vegetation 
dynamics was observed (Batos et al. 2012). Kostić et al. (2021b) analyzed in the common garden experiment early, typical, and late pedunculate oak phenological variety and observed differences in radial growth pattern, drought-sensitiveness, and recovery potential.

\subsection{Genetics and physiology}

In the past, ice ages, as a form of climate change, were one of the basic mechanisms by which the genetic constitutions of populations were formed. During the last ice age, populations of tree species retreated from north to south to avoid climate change. In Europe, three large peninsulas have found habitat, i.e. the Balkan, Apennine, and Iberian peninsulas. In this regard, gene flow between these populations on different peninsulas was not possible, so they formed a certain gene structure. After the glacial period, isolated populations with an already formed new gene structure slowly begin to spread to the north, establishing spatial patterns of chloroplast, mitochondrial, and nuclear genes that have been preserved to this day (Kremer et al. 2002). For example, European oaks showed the same migration before and after the glacial event (Slade, 2001; Slade et al. 2007).

The possible consequences of climate change on genetic diversity may include low reproductive success and a reduction in density of individuals. These two causes have led to the decrease in population size, which is a subject to genetic drift and inbreeding and thereby to reduction in genetic diversity (Bawa and Dayanandan, 1998). Two fundamental processes were defined in which global climate change may affect genetic diversity (Pauls et al. 2013): (1) change in the geographical location and (2) changes in the natural selection. Cobben et al. (2011) and Arena et al. (2012) showed that the population of a shifting range under climate change has low levels of genetic diversity. This is caused by recurring founder effects, allele surfing and because only a part of the original genetic variation moves to a newly colonized habitat (Mandák et al. 2005).

Climate change poses a major threat to populations on the edge of their distribution, although such populations have high values of allelic richness and heterozygosity and we could freely say that they represent reservoirs of biodiversity (Lira-Noriega and Manthey, 2014). For example, the distribution of pedunculate oak in Serbia is marginal and showed high allelic richness and heterozygosity in comparison to central pedunculate oak populations (Kesić et al. 2021). In the future, peripheral populations could disappear due to changing climate conditions in marginal populations and climate change, as predicted by some scenarios (Stojanović et al. 2014).

Numerous studies have addressed the impact of climate change on the physiological processes of woody plants (Ryan, 1991; Ceulemans, 1997; Inoue et al. 2020; Kim et al. 2021). The studies were mainly based on the influence of elevated temperature and $\mathrm{CO}_{2}$ on physiological processes (El Kohen et al. 1993; Mousseau et al. 1996). Primarily, an increase in $\mathrm{CO}_{2}$ in the atmosphere affects the increase in photosynthesis. However, the response to an increase in $\mathrm{CO}_{2}$ in the atmosphere varies greatly depending on the species, growing conditions and period of exposure. For example, an increase in $\mathrm{CO}_{2}$ concentration (400 and $1000 \mu \mathrm{mol} \mathrm{mol}{ }^{-1}$ ) with four photoperiods regimes (growing season photoperiods at $48 \mathrm{~h}$ ) affected an increase in net photosynthesis and chlorophyll fluorescence of Populus tremuloides Michx. (Inoue et al. 2020). Moreover, European beech showed higher response to $\mathrm{CO}_{2}$ than other tree species such as sweet chestnut (El Kohen et al. 1993; Mousseau et al. 1996). Moreover, raised $\mathrm{CO}_{2}$ levels also affect transpiration (Dusenge et al. 2019), water-use-efficiency (Souza et al. 2019), stomatal conductance (Medlyn et al. 2001) and internal $\mathrm{CO}_{2}$ concentration (Menezes-Silva et al. 2019). In addition to temperature and $\mathrm{CO}_{2}$ concentration, drought is an additional factor influencing physiological processes. Vaštag et al. (2020a) showed that the leaf anatomy and chlorophyll fluorescence under drought influence the sensitivity of photosynthetic processes of $Q$. robur L. half-sib lines. Moreover, Stojnić et al. (2020) demonstrated that physiological parameters (intercellular $\mathrm{CO}_{2}$ concentration, transpiration, stomatal conductance, net photosynthesis, intrinsic water-use efficiency, and chlorophyll content) in $Q$. robur half-sib lines were mainly the result of the plants' structural acclimation to drought. Also, environmental conditions were studied in several urban areas. For example, Kesić et al. (2020) showed that some Tilia tomentosa Moench. genotypes had better 
physiological performance in comparison to other genotypes. Moreover, Vaštag et al. (2019) and Vaštag et al. (2020b) suggested that some tree species (e.g. Liquidambar stryraciflua L.) could be more suitable for the changed urban environment.

Climate change also impacts tree phenology, which is split into two phases: (1) bud phenology, encompassing the timing of bursting and (2) growth phenology, encompassing the duration of growth phases (Mohren et al. 1997). In many cases, higher temperatures have been shown to speed up plant development (Saxe et al. 2001) and lead to earlier incidence of switches to the next ontogenetic stage. For example, higher temperatures have caused earlier bud bursts of most tree species (Menzel et al. 2001; Scheifinger et al. 2002; Schaber, 2003).

\subsection{Pests and diseases}

Climate change has been associated with the rise in global temperatures and increased frequency and intensity of extreme weather events like "heat waves", drought, storms and floods that can affect forest resilience at multiple scales, including the emergence of pests and diseases. Temperature is an important factor that directly influence ectotherms like insect herbivores by affecting their speed of development, reproduction, and winter survival. Thus, higher temperatures have caused a disruption of phenological synchrony between host plants and herbivorous insects and have led to extended growing seasons that have altered the distribution, phenology, and population dynamics of insect pests. Moreover, increase in global trade (especially wood products and plants for planting) has led to the emergence of invasive species spreading beyond their native range and multiplying, with negative environmental outcomes on the new ecosystem (Jakoby et al. 2018; Wermelinger et al. 2021).

An example is Corythucha arcuata Say (Heteroptera: Tingidae), the oak lace bug, an insect native in North America that was first reported in Europe in 2000 in Italy (Bernardinelli and Zandigiacomo, 2000) and since then has spread all over the continent. In its native range in North America C. arcuata is not considered a significant pest. However, in Europe a combination of suitable host trees, environmental conditions and the absence of effective natural enemies have caused its populations to flourish (Paulin et al. 2020). In Serbia, C. arcuata was first found in 2013 (Poljaković-Pajnik et al. 2015; Pap et al. 2015) and since then it has caused huge ecological damage, mainly by its negative influence on the production of acorns and natural regeneration. This is because $C$. arcuata adults and nymphs feed on the undersides of the leaves which negatively affects leaf photosynthetic activity and heavy infestations may even cause premature leaf fall followed by branch die-back (Pap et al. 2018; Nikolić et al. 2019).

Another example is bark beetles (Coleoptera: Curculionidae: Scolytinae) which are among the most ecologically and economically important insects of coniferous trees. Higher temperatures have caused an increase in developmental rates of insect pests and consequently, in many countries in Europe bark beetles are now producing more than one complete generation per year. Moreover, as the climate warmed the beetles have expanded to new territories, e.g., the border of survival of a spruce bark beetle, I. typographus in Europe has moved north. Moreover, in recent years, there has been an alarming increase in incidence of bark beetle outbreaks in Europe and North America (Ogris and Jurc, 2010; Hlasny et al. 2019). In Serbia, outbreaks of I. typographus and Pytiogenes chalcographus L. have led to extensive mortality of $P$. abies causing severe ecological and economic losses (Markovic and Stojanovic 2010; Tabakovic-Tosic and Milosavljevic, 2015; Matovic et al. 2016). For example, Matovic et al. 2016 showed that three extremely dry and hot years (2011-2013) have led to physiological weakening of $P$. abies trees on Mt. Kopaonik, resulting in a huge outbreak of I. typographus and P. chalcographus in 2015 and 2016, and consequently mass die-back of trees and mortality of the whole forest stands (Figure 3).

Bark beetles spend their lifetime in an "evolutionary marriage" with several symbionts including fungi, bacteria, viruses, nematodes, and mites. Most bark beetles breed only in dead trees and play a valuable role in nutrient cycling. However, a few outbreaking species (e.g., Ips typographus L. in Europe) attack stressed and dying trees when their populations are low. However, after they build up massive population sizes, they attack healthy trees by pheromone-mediated mass attacks where hundreds of beetles attack a single tree and then spread rapidly over wide areas (Boone et al. 2011; Hlasny et al. 
2019). The beetle success in overcoming chemical and anatomical defence mechanisms of healthy trees has been partially ascribed to simultaneous infections by associated fungi and bacteria which directly or indirectly (by neutralization of tree defences through the production of tree metabolites such as terpenes and phenolics) support tree killing (Six and Wingfield, 2011; Boone et al. 2013; Krokene, 2015).

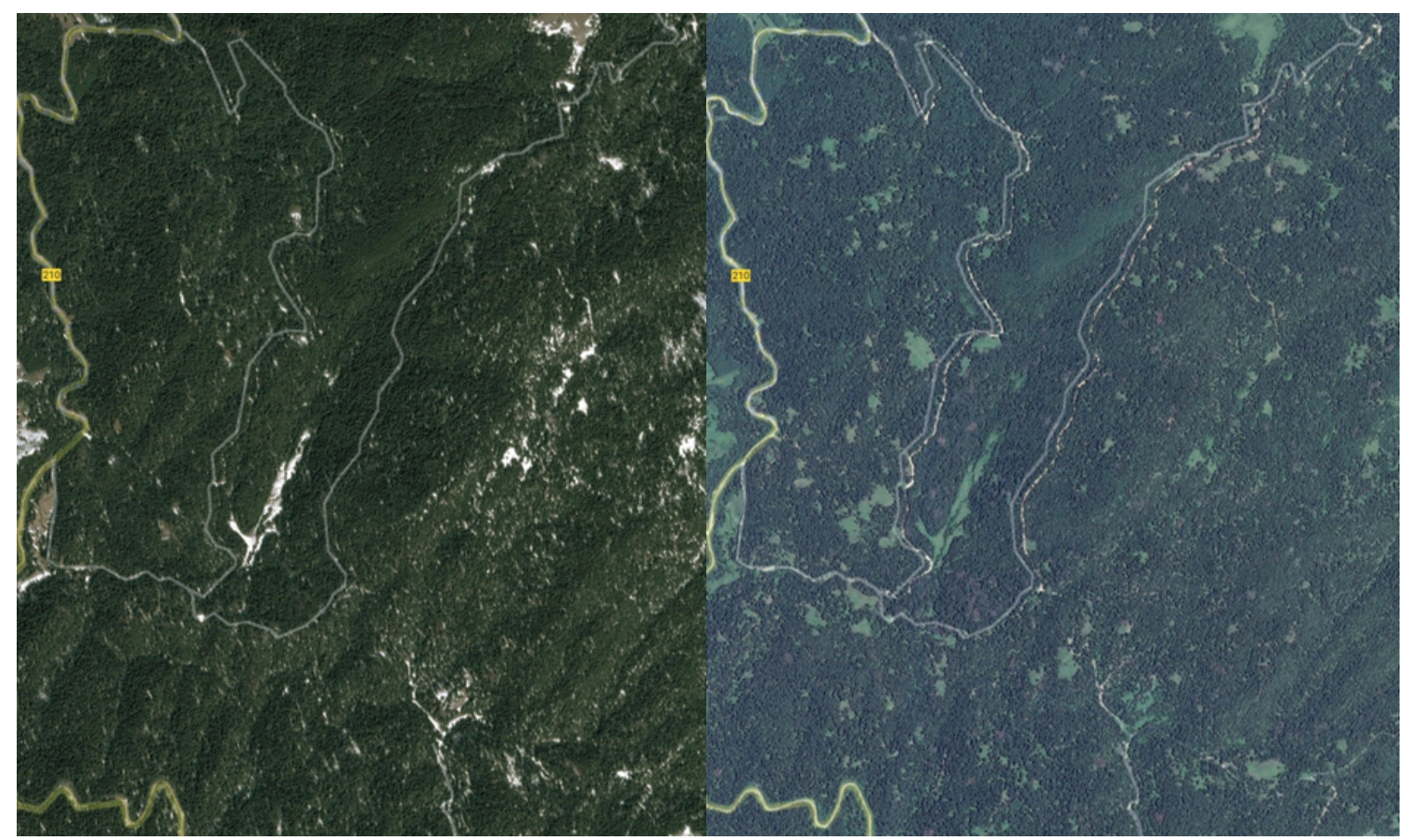

Figure 3. Changes in the forest cover resulting from mass mortality of Picea abies trees at locality "Ravni Kopaonik" in the National Park "Kopaonik" (year 2014 left; year 2017 right) (source: Google Earth).

Bark beetle-associated tree mortality is the result of complex interactions between the number of available host trees and their susceptibility, population size, colonization density, reproduction, microbial symbionts (e.g., fungi and bacteria), and the regulation of these pests by natural enemies (e.g., predators and parasitoids). Climate change has driven changes in tree condition increasing or decreasing secondary defences, phloem nutrients and moisture, and it has affected growth and reproduction of symbionts associated with beetles as well as interactions among symbionts, beetles, and trees thus adding more to the complexity of the multitrophic system (Korokene, 2015; Wermelinger et al. 2021). For example, climate change induced increase in drought events and consequently changes in conifer host physiology have led to an increase in susceptibility of trees to bark beetle attack (Krokene, 2015; Netherer et al. 2021). Resistance traits of conifers against bark beetles and their associated fungi include induced chemical defences in the form of traumatic resin ducts and the biosynthesis of flavonoids, polyphenols and terpenoid oleoresin that entrap and intoxicate attacking beetles and inhibit the growth of fungal symbionts (Schiebe et al. 2012; Hammerbacher et al. 2019). However, in trees that suffer from drought stress reduced carbon uptake due to stomatal closure and low tissue water potentials reduces tree defence abilities by reducing carbon available for resin production, resin flow or prevent its translocation (Krokene, 2015; Netherer et al. 2021).

Climate change has influenced all components of the disease triangle, including a susceptible host, virulent pathogen, and environment favourable for the disease development. Moreover, international trade has increased dramatically over the last decade and this has created conditions for the appearance and spread of invasive pathogens to areas where the pathogen and the host population have never co-evolved, and thus the host has no co-evolved resistance (Grosdidier et al. 2018). In addition, climate extremes like "heat waves" and drought are known to predispose host to pathogen infection through suppression of disease resistance mechanisms. For example, opportunistic and thermophilic pathogens such as Botryosphaeriaceae (Ascomycota: Botryosphaeriales) have benefited 
from changed environmental conditions and in the last decade the incidence of diseases caused by these fungi has dramatically risen worldwide, including Serbia (Zlatkovic 2017, 2018, Zlatkovic et al. 2019; Batista et al. 2021). The impact of these fungi is greatest in urban environments where stress conditions are exacerbated due to the "heat island effect", soil compaction, air pollution and several other stress factors typical for urban areas (Zlatkovic et al. 2016). In contrast, increases in temperatures are predicted to limit the development of ash die-back disease caused by invasive fungal pathogen Hymenoscyphus fraxineus (T. Kowalski) Baral that was introduced to Europe from Asia. In vitro experiments have shown that the optimal growth temperature of the fungus is around $20^{\circ} \mathrm{C}$, while temperatures above $30^{\circ} \mathrm{C}$ are lethal to the pathogen. This significantly limits the possibilities for $H$. fraxineus survival and spread in the warmer world (Grosdidier et al. 2018) and it may also limit its survival and development in Serbia (see above for the discussion on projected increases in temperature). Moreover, we can speculate that the recent increase in the duration and frequency of climate extremes (storms, flooding, drought, heavy rainfall) in Serbia has made trees under stress and provoked infections by several new fungal and bacterial pathogens in hybrid poplar plantations, including Lonsdalea populi (Zlatkovic et al. 2020). Unusually humid and warm summers such as those observed in Serbia in the last years create a perfect environmental condition for the infection and spread of bacterial pathogens (Agrios, 2005). This is in accordance with the fact that even with the presence of aggressive invasive pathogens, conducive environment has often been directly correlated with severe disease impact (Grosdidier et al. 2018).

Outbreaks of insect pests and disease epidemics have long lasting impacts on forest ecosystems and societies, including reduction of carbon storage, disruption of timber supply, impacts on regional economies, and social values (Wermelinger et al. 2021). Therefore, ways to mitigate damage from insect pests and diseases as well as adaptive management strategies are urgently needed in climate stressed forests in Serbia, and worldwide.

\subsection{Ground vegetation}

Ground vegetation is an important part of the forest ecosystem. It contributes significantly to biodiversity and plays an important role in the biocycles of both water and nutrients within the ecosystem (Kolari et al. 2006; Burianek et al. 2013; Kutnar et al. 2019). Numerous domestic and foreign studies concerning the relationship between the forest vegetation and the environment show that any change in abiotic factors can lead to considerable changes in the vegetation (Lindner et al. 2010; Bell et al. 2016; Kutnar et al. 2019). One of the global problems most ecosystems have been facing during recent decades is climate change. It is generally known that vegetation cover responds to environmental changes with great sensitivity and with appropriate speed is hence knowledge on broad-scale changes in the composition and abundance of different plant species and species groups important for both forest conservation and management. Some studies already indicate that that forest vegetation has responded to increasing temperatures (Kuchler et al. 2014; Savage and Vellwnd, 2015). During recent years, biodiversity and its assessment have occupied an important position in the International Cooperative Programme on Assessment and Monitoring of Air Pollution Effects on Forests (ICP Forests), to obtain detailed information on processes within forest ecosystems. The main goal of the monitoring programme is to detect and investigate the extent of changes within forest ecosystems. Within the monitoring, assessment of ground floor vegetation is performed across European forests since changes in the abundance and composition of ground vegetation serve as useful indicators of ongoing changes in site conditions (Seidling, 2005; Burianek et al. 2013; Vasic et al. 2020) or other important factors, such as climate change.

\subsection{Forest mycorrhizae}

Beside its influence on forest trees and ground vegetation, the ongoing climate change have also multi-faceted effects on the soil properties and soil microorganisms. The stability of forest ecosystems and the carbon balance depend to a large degree on the interactions between trees and mycorrhizal 
fungi, especially under disturbance such as climate change (Milović et al. 2021). Mycorrhizal fungi which make mutualistic association with more than $90 \%$ of plant species, represent the key players in carbon dynamics and carbon fluxes among plants, soil, and the atmosphere (Smith and Read, 2008). They obtain water and nutrients from the soil and deliver them to the host plant in exchange for carbohydrates produced in photosynthesis (Smith and Read, 2008; Simard and Austin, 2010).

Mycorrhizal fungi have crucial role in linking aboveground and belowground components of forest ecosystems through common mycelial network. Also, these networks connect plants of the same or different species and can influence the physiological and ecological processes of plants because they facilitate nutrient exchange between plants, change competitive abilities of plants and serve as reservoirs of inoculum for seedlings (Selosse et al. 2006). Furthermore, mycorrhizal fungi have crucial role in forest regeneration, succession, and resistance against numerous stress factors (Selosse et al. 2006; Smith and Read, 2008; Simard and Austin, 2010).

Their most important role of mycorrhizal fungi in forest ecosystems under conditions of climate change may be in their stabilizing effects on forests trees that are under increasing environmental stress (Milović et al. 2021). Numerous studies showed that mycorrhizas have an important role in the resilience and recovery of forests under climate change, by mitigating detrimental effects of $\mathrm{CO}_{2}$ enrichment, temperature rise, drought, lack of nutrients, soil acidification, pollutants, pests, and diseases (Simard and Austin, 2010; Milović et al. 2021).

\subsection{Monitoring, reporting and verification (MRV) system in the context of forestry}

Extreme weather conditions such as drought, heat waves, heavy rain, floods and landslides are becoming more frequent globally and in Serbia as a result of climate change. In order to limit global warming to $1.5^{\circ} \mathrm{C}-$ a threshold the Intergovernmental Panel for Climate Change (IPCC) suggests is safe - carbon neutrality by mid-21 st century is essential. This target is also laid down in the Paris agreement signed by 195 countries, including Serbia. Carbon neutrality means having a balance between emitting carbon and absorbing carbon from the atmosphere in carbon sinks that are any systems that absorb more carbon than they emit, such as forests, soils and oceans.

Confirmation of achievement of carbon neutrality requires "a carbon accounting framework" or transparent, consistent and accurate national monitoring, reporting and verification system (MRV). Important part of that system is MRV of the carbon stored in forests. The bulk of work involved in MRV is closely related to the more general forest and land information systems needed for sustainable forest management and land use policies. The Measurement components of MRV system usually consist of:

- Forestry/Land Monitoring System to assess activity data on forest area and forest area changes,

- Forest Inventory to assess emission factors on carbon stocks and carbon stock changes,

- Monitoring of implementation of policies in the forestry sector.

These systems provide input to the Reporting component, compiling:

- The land use and forestry sector input to the National GHG Inventory,

- Information on achievement of forestry related goals as input in the MRV Policy and Measure (PAMs) system.

Finally, the Verification component of the MRV system includes systems for assessment of the completeness, consistency and reliability of the information. This could be done by the responsible organization itself as well as by independent parties, and as such is important for tracking achievement of climate change mitigation commitments of Serbian Government.

In addition, activity data on forest area and forest area changes are of importance for monitoring of climate change impacts on forests providing a basis for vulnerability assessment. For comprehensive analysis of these impacts, monitoring of biodiversity, vegetation, pests and diseases is required. Moreover, monitoring of implementation of policies in the forestry sector ensures evaluation of success of their implementation and implemented adaptation and mitigation measures. 


\subsection{Climate change litigation (CCL)}

Until 2017 there were 884 court cases in 24 countries, while Until 1 July 2020 there were 1550 cases in 38 countries, from which more than $70 \%$ of cases were in United States, according to United Nations Environment Programme Report about Climate Change Litigation (Zhongming et al. 2021). According to the same report climate cases can be divided into six categories:

i) climate rights

ii) domestic enforcement

iii) keeping fossil fuels in the ground

iv) corporate liability and responsibility

v) failure to adapt and the impacts of adaptation

vi) climate disclosures and greenwashing.

Implication of climate change litigation to forestry can be seen in lawsuits filled in Brazil, where government decisions regarding regulations on timber harvesting in Amazon and forest funds for reforestation were challenged. In European Union, accounting of $\mathrm{CO}_{2}$ in forest biomass as a renewable fuel according to Renewable Energy Directive (2018) were challenged by plaintiffs from several countries without success. They stated that Directive will lead to further devastation of forests.

International experience is that climate litigation lawsuits usually go in the way of forcing governments to act or from the other side ii) to prevent relaxation ("deregulation") of climate related laws by government. Until now, to the best of our knowledge, there is no data about lawsuits regarding climate related topics in the Serbian justice system.

To the best of authors knowledge, there were no court cases of climate change litigation in Serbian forestry.

\subsection{Forests in the $21^{\text {st }}$ century in Serbia}

In the future, the rise in global air temperature will change the existing climate. Northern regions of Europe, as well as regions at higher altitudes, will become a more favourable habitat for most nowadays known tree species of semi climate regions (Tian et al. 2016; Bellard et al. 2012; Dyderski et al. 2018). According to the SRES A1B and A2 climate scenarios the distribution of most present tree species in Serbia will change by the end of $21^{\text {st }}$ century. Moreover, it is expected that the area of beech forests in Serbia will decrease (Pavlovic et al. 2019). According to the A1B climate scenario, the area covered by beech in Serbia could decrease up to $56 \%$ by 2100 . A similar reduction is expected according to the A2 climate scenario, i.e. a decrease of $58 \%$ by 2100 . A decrease in the area covered by European beech (Fagus sylvatica L.) is also expected in most parts of the European continent (Dulamsuren et al. 2016; Pecl et al. 2017), and, as well as a decrease of distribution of Oriental beech (Fagus orientalis) Lipsky) (Dagtekin et al. 2020). Furthermore, a decrease in the area covered by Turkey oak (Quercus cerris L.), Pedunculate oak (Quercus robur L.) and Sessile oak (Quercus petraea (Matt.) Liebl.) is expected. According to the A1B climate scenario, a reduction in the distribution of Turkey oak could be up to one third of the today's habitats, whereas according to the A2 scenario, the reduction could be up to $48 \%$ by the end of the $21^{\text {st }}$ century. Pedunculate oak range could be potentially reduced by $61 \%$, and $70 \%$, according to the $\mathrm{A} 1 \mathrm{~B}$ and $\mathrm{A} 2$ scenarios, respectively. The potential reduction of sessile oak habitats according to the A1B climate scenario could be up to one half by 2100 , and $63 \%$ according to the A2 climate scenario. Drought periods are likely to increase in Serbia (MZŽS, 2017), and this could be one of the reasons for the reduction of area covered by sessile oak. The sensitivity of sessile oak to drought periods was also noticed by Jakucs et al. (1986). In addition, the potential habitat expansion is expected for Italian oak (Quercus frainetto Ten.) For example, according to the A2 climate scenario, habitat expansion of $Q$. frainetto is predicted to be $66 \%$ higher when compared to today's distribution of the species. An increase in the Italian oak range could be expected due to its ability to grow in dry conditions (Apostol et al. 2020). 
The expectation is also that the distribution of silver fir (Abies alba Mill.), Norway spruce (Picea abies (L.) and pines (black pine - Pinus nigra JF Arnold; Scots pine - Pinus sylvestris L.) will decrease. According to the $\mathrm{A} 1 \mathrm{~B}$ and $\mathrm{A} 2$ climate scenarios the projected reduction of silver fir distribution range by 2100 could be from one-fifth to one-third of today's species's habitat, respectively. Spruce (Picea abies (L.) distribution range is expected to be drastically reduced by the end of the $21^{\text {st }}$ century, i.e. $70 \%$ and $77 \%$ according to A1B and A2 climate scenarios, respectively. Moreover, according to the A1B climate scenario the range of black pine (Pinus nigra J. F. Arnold) and Scots pine (Pinus sylvestris L.) is likely to be reduced by up to $22 \%$ by the end of the 21 st century, and by up to $31 \%$ according to the A 2 climate scenario. It is assumed that the area of Scots pine would be reduced, while Black pine would retain most of its current range.

The latest research on the potential impact of climate change on forests in Serbia, using climate indices (Forestry Aridity Index - FAI and Ellenberg Quotient - EQ), has yielded very interesting results. Miletić et al. (2021) found that from mid (2041-2070) to late 21st century (2071-2100) under the RCP 4.5. (which has lower $\mathrm{CO}_{2}$ emission levels than e.g. A1B and A2 from Assessment Report 4 of The Intergovernmental Panel on Climate Change for $21^{\text {st }}$ century) scenario reduction rates of Norway spruce and Silver fir suitable habitats are relatively small and constant and will not exceed $25 \%$. These changes are expected to happen on eastern and southern "borders" of their distribution at lower elevations. On the other hand, slightly higher reduction rates (up to 35\%) are expected for European beech and Black pine with Scots pine in the south and southeast and, to a lesser extent, in the east and west only for European beech. However, a small expansion of suitable habitats for Black and Scots pine in the east can be expected as part of these changes. According to Miletić et al. (2021) RCP 8.5 (similar to the A2 scenario in the overall $\mathrm{CO}_{2}$ values at 2100, but with slightly different concentration curve shape) projections until 2070 suggest that 55 (FAI) to 75\% (EQ) of Norway spruce, Silver fir, European beech and Black and Scots pine existing habitats will remain intact. Existing Norway spruce sites in the southeast and a few sites of Silver fir in the east are expected to be affected by climate change. The same goes for pines and European beech. As we approach towards the end of the century results are becoming very stressful, as they are indicating that 75-85\% (EQ) to $90-100 \%$ (FAI) of the Norway spruce, Silver fir, European beech and pines habitats will be found outside of their current climate space.

Generally, it is expected that heat waves will become more intensive and more frequent than in the past, reaching two to seven occurrences during the year before 2100, which is great opposite to the period; e.g. 1986-2005, when they were very unusual events (Djurdjevic et al. 2018; Vukovic et al. 2018). Seasonal and annual weather changes are expected, such as rise of temperatures, decrease of frost and icing days, increase of very hot days (above $35^{\circ} \mathrm{C}$ ), increase of days without precipitation as well as increase of days with very heavy precipitation (above $20 \mathrm{~mm}$ ) (Vuković and Vujadinović Mandić, 2018), which will certainly have complex effects on forest ecosystems that need to be perceived, thoroughly monitored and researched.

\section{Acknowledgments}

This research was supported by the Science Fund of the Republic of Serbia, PROMIS, \#6066697, TreeVita and by the Ministry of Education, Science and Technological Development of the Republic of Serbia (451-03-9/202114/200197).

\section{References}

1. Agrios, G.N. (2005): Plant pathology, $5^{\text {th }}$ edition. Elsevier Academia Press. San Diego Calf. USA.

2. Apostol, E.N., Stuparu, E., Scarlatescu, V., Budeanu. M. (2020): Testing hungarian oak (Quercus frainetto Ten.) provenances in Romania. iForest - Biogeosciences and Forestry 13(1): 9-15.

3. Arenas, M., Ray, N., Currat M., Excoffier, L. (2012): Consequences of range contractions and range shifts on molecular diversity. Molecular Biology and Evolution 29: 207-218. 
4. Banković, S., Medarević, M., Pantić, D., Petrović, N. (2009): National Forest Inventory of the Republic of Serbia. [in Serbian] Ministry of Agriculture, Forestry and Water Management of the Republic of Serbia, Forest Directorate, Belgrade.

5. Batista, E., Lopes, A., Alves, A. (2021): What do we know about Botryosphaeriaceae? An overview of a worldwide cured dataset. Forests 12(3): 313.

6. Batos, B., Miljkovic, D., Ninic-Todorovic, J. (2012): Length of vegetation period as parameter of common oak (Quercus robur L.) phenological variability. Genetika 44(1): 139-152.

7. Bawa, K. S., Dayanandan, S. (1998): Global climate change and tropical forest genetic resources. Climatic change 39(2): 473-485.

8. Bell, F.W., Lamb, E.G., Sharma, M., Hunt, S., Anand, M., Dacosta, J., Newmaster, S.G. (2016): Relative influence of climate, soils, and disturbance on plant species richness in northern temperate and boreal forests. Forest Ecology and Management 381: 93-105.

9. Bellard, C., Bertelsmeier, C., Leadley, P., Thuiller, W., Courchamp, F. (2012): Impacts of Climate Change on the Future of Biodiversity. Ecology Letters 15 (4): 365-77.

10. Bernardinelli, I., Zandigiacomo, P. (2000): Prima segnalazione di Corythucha arcuata (Say) (Heteroptera, Tingidae) in Europa. Informatore Fitopatologico 50: 4-49.

11. Boone, C.K., Aukema, B.H., Bohlmann, J., Carroll, A.L., and Raffa, K.F. (2011): Efficacy of tree defense physiology varies with bark beetle population density: a basis for positive feedback in eruptive species. Canadian Journal of Forestry Research 41: 1174-1188.

12. Boone, C.K., Keefover-Ring, K., Mapes, A.C., Adams, A.S., Bohlmann, J., Raffa, K.F. (2013): Bacteria associated with a tree-killing insect reduce concentrations of plant defense compounds. Journal of Chemical Ecology 39: 1003-1006.

13. Burianek, V., Novotny, R., Hellebrandova, K., Sramek, V. (2013): Ground vegetation as an important factor in the biodiversity of forest ecosystems and its evaluation in regard to nitrogen deposition. Journal of Forest Science 59: 238-252.

14. Ceulemans, R. (1997): Direct impacts of $\mathrm{CO}_{2}$ and temperature on physiological processes in trees. Impacts of global change on tree physiology and forest ecosystems, 3-14.

15. Cobben, M.M.P., Verboom, J., Opdam, P.F.M. (2011): Projected climate change causes loss and redistribution of genetic diversity in a model metapopulation of a medium-good disperser. Ecography 34: 920-932.

16. Cornes, R., van der Schrier, G., van den Besselaar, E.J.M., Jones, P.D. (2018) An ensemble version of the E-OBS temperature and precipitation datasets. Journal of Geophysical Research: Atmospheres 123(17): 9391-9409.

17. Dagtekin, D., Şahan, E.A., Denk, T., Köse, N., Dalfes, H.N. (2020): Past, Present and Future Distributions of Oriental Beech (Fagus orientalis) under Climate Change Projections. PLOS ONE 15 (11): e0242280.

18. Djurdjevic, V., Vukovic, A., Vujadinovic Mandic, M. (2018): Observed Climate Change in Serbia and Climate-Based Future Projections of Different Emission Scenarios. UNDP Serbia. https://www.klimatskepromene.rs/wp-content/uploads/2021/08/Osmotrene-promene-klime-iprojekcije-buduce-klime.pdf

19. Dyderski, M.K., Paź, S., Frelich, L.E., Jagodziński, A.M. (2018): How much does climate change threaten european forest tree species distributions? Global Change Biology 24(3): 1150-63.

20. Dulamsuren, C., Bayerisches, M.R, Leuschner, C. (2017): European beech responds to climate change with growth decline at lower, and growth increase at higher elevations in the center of its distribution range (SW Germany). Trees 31: 673-686.

21. Dusenge, M. E., Duarte, A. G., Way, D. A. (2019): Plant carbon metabolism and climate change: elevated $\mathrm{CO}_{2}$ and temperature impacts on photosynthesis, photorespiration and respiration. New Phytologist 221(1): 32-49.

22. El Kohen, A., Venet, L., Mousseau, M. (1993): Growth and photosynthesis of two deciduous forest species at elevated carbon dioxide. Functional Ecology: 480-486. 
23. Grosdidier, M., Ioos, R., Marçais, B. (2018): Do higher summer temperatures restrict the dissemination of Hymenoscyphus fraxineus in France?. Forest Pathology 48(4): e12426.

24. Hammerbacher, A., Kandasamy, D., Ullah, C., Schmidt, A., Wright, L. P., Gershenzon, J. (2019): Flavanone-3-hydroxylase plays an important role in the biosynthesis of spruce phenolic defenses against bark beetles and their fungal associates. Frontiers in Plant Science 10: 208.

25. Hijmans, J. R. (2020): Raster: geographic data analysis and modelling. R package version 3.012.

26. Hlásny, T., Krokene, P., Liebhold, A., Montagné-Huck, C., Müller, J., Qin, H., Raffa, K. et al. (2019): Living with bark beetles: impacts, outlook and management options. No. 8. European Forest Institute.

27. Inoue, S., Dang, Q. L., Man, R., Tedla, B. (2020): Photoperiod and $\mathrm{CO}_{2}$ elevation influence morphological and physiological responses to drought in trembling aspen: implications for climate change-induced migration. Tree Physiology 40(7): 917-927.

28. IPCC (2021): Summary for Policymakers. In: Masson-Delmotte, V., Zhai, P., Pirani, A., Connors, S.L., Péan, C., Berger, S., Caud, N., Chen, Y., Goldfarb, L., Gomis, M.I., Huang, M., Leitzell, K., Lonnoy, E., Matthews, J.B.R., Maycock, T.K., Waterfield, T., Yelekçi, O., Yu, R., Zhou, B. (eds.). Climate Change 2021: The Physical Science Basis. Contribution of Working Group I to the Sixth Assessment Report of the Intergovernmental Panel on Climate Change. Cambridge University Press. [In Press]

29. Jakoby, O., Lischke, H., Wermelinger, B. (2019): Climate change alters elevational phenology patterns of the European spruce bark beetle (Ips typographus). Global change biology 25(12): 4048-4063.

30. Jakucs, P., Mészáros, I., Papp, B., Tóth, J. (1986): Acidification of soil and decay of sessile oak in the 'Sikfokut Project' area (N-Hungary). Acta Botanica Hungarica 32 (1): 303-322.

31. Kesić, L., Cseke, K., Orlović, S., Stojanović, D.B., Kostić, S., Benke, A., Borovics, A., Stojnić, S., Avramidou, E.V. (2021): Genetic diversity and differentiation of pedunculate oak (Quercus robur L.) populations at the southern margin of its distribution range - implications for conservation. Diversity 13(8): 371.

32. Kesić, L., Vuksanović, V., Karaklić, V., Vaštag, E. (2020): Variation of leaf water potential and leaf gas exchange parameters of seven Silver linden (Tilia tomentosa Moench) genotypes in urban environment. Topola 205: 15-24.

33. Kim, T.L., Chung, H., Veerappan, K., Lee, W.Y., Park, D., Lim, H. (2021): Physiological and transcriptome responses to elevated $\mathrm{CO}_{2}$ concentration in Populus. Forests 12(8): 980.

34. Kolari, P., Pumpanen, J., Kulmala, L., Ilvesniemi, H., Nikinmaa, E., Grönholm, T., Hari, P. (2006): Forest floor vegetation plays an important role in photosynthetic production of boreal forests. Forest Ecology and Management 221(1-3): 241-248.

35. Kostić, S., Kesić, L., Matović, B., Orlović, S., Stojnić, S., Stojanović, D. B. (2021a): Soil properties are significant modifiers of pedunculate oak (Quercus robur L.) radial increment variations and their sensitivity to drought. Dendrochronologia 67: 125838.

36. Kostić, S., Levanič, T., Orlović, S., Matović, B., Stojanović, D. B. (2019): Pedunculate and Turkey oaks radial increment and stable carbon isotope response to climate conditions through time. Topola 204: 29-35.

37. Kostić, S., Orlović, S., Karaklić, V., Kesić, L., Zorić, M., Stojanović, D. B. (2021b): Allometry and post-drought growth resilience of pedunculate oak (Quercus robur L.) varieties. Forests 12(7): 930.

38. Kostić, S., Wagner, W., Orlović, S., Levanič, T., Zlatanov, T., Goršić, E., Kesić, L., Matović, B., Tsvetanov, N., Stojanović, D.B. (2021c): Different tree-ring width sensitivities to satellite-based soil moisture from dry, moderate and wet pedunculate oak (Quercus robur L.) stands across a southeastern distribution margin. Science of The Total Environment 800: 149536.

39. Kremer, A., Kleinschmit, J., Cottrell, J., Cundall, E. P., Deans, J. D., Ducousso, A., Stephan, B. R. (2002): Is there a correlation between chloroplastic and nuclear divergence, or what are the 
roles of history and selection on genetic diversity in European oaks? Forest Ecology and Management 156(1-3): 75-87.

40. Krokene, P. (2015): Conifer defense and resistance to bark beetles. In: Hofstetter, R.W., Vega, F.E. (eds). Bark Beetles: Biology and Ecology of Native and Invasive Species. Elsevier, Amsterdam. pp. 177-207.

41. Kutnar, L., Nagel, T. A., Kermavnar, J. (2019): Effects of disturbance on understory vegetation across Slovenian forest ecosystems. Forests 10: 1048.

42. Kuchler, M., Kuchler, H., Bedolla, A., Wohlgemuth, T. (2014): Response of Swiss forests to management and climate change in the last 60 years. Annals of Forest Science 72: 311-320.

43. Lindner, M., Maroschek, M., Netherer, S., Kremer, A., Barbati, A., Garcia-Gonzalo, J., Seidl, R., Delzon, S., Corona, P., Kolström, M., Lexer, M.J., Marchetti, M. (2010): Climate change impacts, adaptive capacity, and vulnerability of European forest ecosystems. Forest Ecology and Management 259(4): 698-709.

44. Lira-Noriega, A., Manthey, J.D. (2014): Relationship of genetic diversity and niche centrality: a survey and analysis. Evolution 68(4): 1082-1093.

45. Mandák, B., Bímová, K., PlačkovÁ, I., Mahelka, V., Chrtek, J. (2005): Loss of genetic variation in geographically marginal populations of Atriplex tatarica (Chenopodiaceae). Annals of Botany 96(5): 901-912.

46. Matović, B., Orlović, S., Galić, Z., Marković, M., Poljaković-Pajnik, L., Pap, P., Drekić, M., Pilipović, A., Stojnić, S., Stojanović, DB., Kebert, M., Trudić, B. (2016): Multidisciplinarna istraživanja procesa sušenja šuma. Finalni izveštaj projekta finansiranog od Ministarstva poljoprivrede, šumarstva i vodoprivrede, Uprave za šume (2015-2016. godine).

47. Matović, B., Stojanović, D., Kesić, L., Stjepanović, S. (2018): Uticaj klime na rast i vitalnost smrče na Kopaoniku. Topola 201-202: 99-116.Markovic, C., Stojanovic, A. (2010): Differences in bark beetle (Ips typographus and Pityogenes chalcographus) abundance in a strict spruce reserve and the surrounding spruce forests of Serbia. Phytoparasitica 38: 31-37.

48. Medlyn, B.E., Barton, C.V.M., Broadmeadow, M.S.J., Ceulemans, R., De Angelis, P., Forstreuter, M., Jarvis, P.G. (2001): Stomatal conductance of forest species after long-term exposure to elevated $\mathrm{CO}_{2}$ concentration: a synthesis. New Phytologist 149(2): 247-264.

49. Menezes-Silva, P.E., Loram-Lourenço, L., Alves, R.D.F.B., Sousa, L.F., Almeida, S.E.D.S., Farnese, F.S. (2019): Different ways to die in a changing world: Consequences of climate change for tree species performance and survival through an ecophysiological perspective. Ecology and evolution 9(20): 11979-11999.

50. Menzel, A., Estrella, N., Fabian, P. (2001): Spatial and temporal variability of the phenological seasons in Germany from 1951 to 1996. Global Change Biology 7(6): 657-666.

51. Miletić, B., Orlović, S., Lalić, B., Đurđević, V., Vujadinović Mandić, M., Vuković, A., Gutalj, M., Stjepanović, S., Matović, B., Stojanović, D.B. (2021). The potential impact of climate change on the distribution of key tree species in Serbia under RCP 4.5 and RCP 8.5 scenarios. Austrian Journal of Forest Science 138 (3): 183-208.

52. Milović M., Kebert M., Orlović S. (2021): How mycorrhizas can help forests to cope with ongoing climate change? Šumarski list 5-6: 279-286.

53. Mohren, G.M.J., Kramer, K., Sabaté, S. (Eds.). (1997): Impacts of global change on tree physiology and forest ecosystems (Vol. 52). Springer Science \& Business Media.

54. Mousseau, M., Dufrene, E., El Kohen, A., Epron, D., Godard, D., Liozon, R., Saugier, B. (1996): Growth strategy and tree response to elevated $\mathrm{CO}_{2}$ : A comparison of beech (Fagus sylvatica) and sweet chestnut. In: Koch, G.W., Mooney, H.A. (eds). Carbon dioxide and terrestrial ecosystems. pp. 71-86.

55. Ministarstvo zaštite životne sredine (2017): Drugi izveštaj Republike Srbije prema Okvirnoj konvenciji Ujedinjenih nacija o promeni klime. Beograd, Republika Srbija.

56. NASA: https://climate.nasa.gov/faq/19/what-is-the-greenhouse-effect/ (accessed 2021). 
57. Netherer, S., Kandasamy, D., Jirosová, A., Kalinová, B., Schebeck, M., Schlyter, F. (2021): Interactions among Norway spruce, the bark beetle Ips typographus and its fungal symbionts in times of drought. Journal of Pest Science 1-24.

58. Nikolić, N., Pilipović, A., Drekić, M., Kojić, D., Poljaković-Pajnik, L., Orlović, S., Arsenov, D. (2019): Physiological responses of pedunculate oak (Quercus robur L.) to Corythucha arcuata (Say, 1832) attack. Archives of Biological Sciences 71: 167-176.

59. NOAA, Global Monitoring Laboratory, https://research.noaa.gov/article/ArtMID/587/ArticleID/2764/Coronavirus-response-barelyslows-rising-carbon-dioxide (accessed 2021).

60. Ogris, N., Jurc, M. (2010): Sanitary felling of Norway spruce due to spruce bark beetles in Slovenia: a model and projections for various climate change scenarios. Ecological Modelling 221(2): 290-302.

61. Pavlović, L., Stojanović, D., Mladenović, E., Lakićević, M., Orlović, S. (2019). Potential elevation shift of the European beech stands (Fagus sylvatica L.) in Serbia. Frontiers in plant science 10: 849 .

62. Pap, P., Drekic, M., Poljakovic-Pajnik, L., Markovic, M., Vasic, V. (2015): Monitoring zdravstvenog stanja šuma na teritoriji Vojvodine u 2015. godini. Topola 195-196: 117-133.

63. Pap, P., Drekić, M., Poljaković-Pajnik, L., Vasić, V., Marković, M., Zlatković, M., Stojanović, D. V. (2018): Monitoring and forecasting of harmful organisms in forests and plantations of Vojvodina, Serbia in 2018. Topola 201-202: 251-274.

64. Paulin, M., Hirka, A., Eötvös, C.B., Gáspár, C., Fürjes-Mikó, Á., Csóka, G. (2020): Known and predicted impacts of the invasive oak lace bug (Corythucha arcuata) in European oak ecosystems - a review. Folia Oecologica 47: 131-139.

65. Pauls, S. U., Nowak, C., Bálint, M., Pfenninger, M. (2013): The impact of global climate change on genetic diversity within populations and species. Molecular ecology 22(4): 925-946.

66. Pecl, G.T., Araújo, B.M., Bell, J.D., Blanchard, J., Bonebrake, T.C., Chen, I., Clark, T.D., et al. (2017): Biodiversity redistribution under climate change: impacts on ecosystems and human well-being. Science 355: 6332.

67. Pierce, D. (2019): ncdf4: Interface to Unidata netCDF (Version 4 or Earlier) Format Data Files. $\mathrm{R}$ package version 1.17.

68. Poljakovic-Pajnik, L., Drekic, M., Pilipovic, A., Nikolic, N., Pap, P., Vasic, V., Markovic, M. (2015): Pojava velikih šteta od Corythucha arcuata (Say) (Heteroptera: Tingidae) u šumama hrasta u Vojvodini. In: XIII savetovanje o zaštiti bilja. 23-26 November 2015, Zlatibor, Serbia.

69. Pretzsch, H., del Río, M., Ammer, C., Avdagic, A., Barbeito, I., Bielak, K.,... Bravo-Oviedo, A. (2015): Growth and yield of mixed versus pure stands of Scots pine (Pinus sylvestris L.) and European beech (Fagus sylvatica L.) analysed along a productivity gradient through Europe. European Journal of Forest Research 134(5): 927-947.

70. R Core Team (2020): R: A language and environment for statistical computing. R Foundation for Statistical Computing, Vienna, Austria.

71. Rađević, V., Pap, P., Vasić, V. (2020): Management of the common oak forests in Ravni Srem: Yesterday, today, tomorrow. Topola 206: 41-52.

72. Ryan, M. G. (1991): Effects of climate change on plant respiration. Ecological Applications 1(2): 157-167.

73. Savage, J., Vellend, M. (2015): Elevational shifts, biotic homogenization and time lags in vegetation change during 40 years of climate warming. Ecography 38: 546- 555.

74. Saxe, H., Cannell, M.G.R., Johnsen, B., Ryan, M.G., Vourlitis, G. (2001): Tree and forest functioning in response to global warming. New Phytologist 149: 369-399.

75. Schaber, J., Badeck, F.W. (2003): Physiology-based phenology models for forest tree species in Germany. International journal of biometeorology 47(4): 193-201.

76. Scheifinger, H., Menzel, A., Koch, E., Peter, C., Ahas, R. (2002): Atmospheric mechanisms governing the spatial and temporal variability of phenological phases in central Europe. 
International Journal of Climatology: A Journal of the Royal Meteorological Society 22(14): 1739-1755.

77. Schiebe, C., Hammerbacher, A., Birgersson, G., Witzell, J., Brodelius, P.E., Gershenzon, J., Hansson, B.S., Krokene, P., Schlyter, F. (2012). Inducibility of chemical defenses in Norway spruce bark is correlated with unsuccessful mass attacks by the spruce bark beetle. Oecologia 170: 183-198.

78. Seidling, W. (2005): Ground floor vegetation assessment within the intensive (Level II) monitoring of forest ecosystems in Germany: Chances and challenges. European Journal of Forestry Research 124: 301-312.

79. Selosse, M.-A., Richard, F., He, X., Simard, S.W. (2006): Mycorrhizal networks: les liaisons dangeureuses? Trends in Ecology and Evolution 21: 621-628.

80. Simard, S., Austin, M. (2010): The role of mycorrhizas in forest soil stability with climate change. In: Simard, S. (eds). Climate Change and Variability. IntechOpen, Rijeka, Croatia. pp. 275-302.

81. Six, D.L., Wingfield, M.J. (2011): The role of phytopathogenicity in bark beetle-fungus symbioses: a challenge to the classic paradigm. Annual Review of Entomology 56: 255-272.

82. Slade, D. (2001): Distribucija haplotipova hrasta lužnjaka (Quercus robur L.) u Hrvatskoj. Magistarski rad - PMF. Zagreb. s87.

83. Slade, D., Škvorc, Ž., Ballian, D., Gračan, J., Papeš, D. (2007): The chloroplast DNA polymorphisms of white oaks of section Quercus in the Central Balkans. Silvae genetica 57(45): 227-234.

84. Souza, J.P., Melo, N.M.J., Halfeld, A.D., Vieira, K.I., Rosa, B.L. (2019): Elevated atmospheric $\mathrm{CO}_{2}$ concentration improves water use efficiency and growth of a widespread Cerrado tree species even under soil water deficit. Acta Botanica Brasilica 33: 425-436.

85. Smith, S.E., Read, D.J. (2008): Mycorrhizal symbiosis, Third edition. Elsevier Academic Press. London, UK.

86. Stjepanović, S., Matović, B., Stojanović, D., Lalić, B., Levanič, T., Orlović, S., Gutalj, M. (2018): The impact of adverse weather and climate on the width of European beech (Fagus sylvatica L.) tree rings in Southeastern Europe. Atmosphere 9(11): 451.

87. Stojanović, D.B., Levanič, T., Matović, B., Orlović, S. (2015): Growth decrease and mortality of oak floodplain forests as a response to change of water regime and climate. European Journal of Forest Research 134(3): 555-567.

88. Stojanović, D., Levanič, T., Matović, B., Stjepanović, S., Orlović, S. (2018): Growth response of different tree species (oaks, beech and pine) from SE Europe to precipitation over time. Dendrobiology 79: 97-110.

89. Stojanović, D.B., Matović, B., Orlović, S., Kržič, A., Trudić, B., Galić, Z., Stojnić, S., Pekeč. (2014): Future of the main important forest tree species in Serbia from the climate change perspective. South-east European forestry: South-East European Forestry 5(2): 117-124.

90. Stojnić, S., Kovačević, B., Kebert, M., Vaštag, E., Bojović, M., Neđić, M. S., Orlovic, S. (2019): The use of physiological, biochemical and morpho-anatomical traits in tree breeding for improved water-use efficiency of Quercus robur L. Forest Systems 28(3): 5.

91. Tabaković-Tošić, M., Milosavljević, M. (2015): Uticaj ekstremnih klimatskih uslova na populacionu dinamiku potkornjaka u šumama Istočne Srbije. Sustainable Forestry: Collection 71-72: 27-37.

92. Xiaohui, T., Sohngen, B., Kim, J.B., Ohrel, S., Cole, J. (2016): Global climate change impacts on forests and markets. Environmental Research Letters 11(3): 35011.

93. Vasic, V., Drekić, M., Poljaković Pajnik, L., Vasić, S., Kesić, L., Galić, Z. (2020): Sastav prizemne flore na bioindikacijskoj tački nivoa II na Fruškoj gori. Topola 206: 35-40.

94. Vaštag, E., Kesić, L., Karaklić, V., Zorić, M., Vuksanović, V., Stojnić, S. (2019): Physiological performance of sweetgum (Liquidambar stryraciflua L.) and norway maple (Acer platanoides L.) under drought condition in urban environment. Topola 204: 17-27. 
95. Vaštag, E., Cocozza, C., Orlović, S., Kesić, L., Kresoja, M., Stojnić, S. (2020a): Half-sib lines of pedunculate oak (Quercus robur L.) respond differently to drought through biometrical, anatomical and physiological traits. Forests 11(2): 153.

96. Vaštag, E., Orlović, S., Konôpková, A., Kurjak, D., Cocozza, C., Pšidová, E., Stojnić, S. (2020b): Magnolia grandiflora L. shows better responses to drought than Magnolia soulangeana in urban environment. iForest-Biogeosciences and Forestry 13(6): 575-583.

97. Vuković, A.J., Vujadinović, M.P., Rendulić, S.M., Đurđević, V.S., Ruml, M.M., Babić, V.P., Popović, D.P. (2018): Global warming impact on climate change in Serbia for the period 19612100. Thermal Science 22(6): 2267-2280.

98. Vuković, A., Vujadinović Mandić, M. (2018). Study on climate change in the Western Balkans region. Bosnia and Herzegovina: Regional Cooperation Council Secretariat. https://www.rcc.int/download/docs/2018-05-Study-on-Climate-Change-in-WB-2alowres.pdf/06af8f7432484a6ce384ebcb8c05e8d7.pdf

99. Wang, X., Wang, C., Gong, P., Wang, X., Zhu, H., Gao, S. (2021): Century-long record of polycyclic aromatic hydrocarbons from tree rings in the southeastern Tibetan Plateau. Journal of Hazardous Materials 412: 125152.

100.Wermelinger, B., Rigling, A., Schneider Mathis, D., Kenis, M., Gossner, M. M. (2021): Climate change effects on trophic interactions of bark beetles in inner Alpine Scots pine forests. Forests 12(2): 136.

101.Zlatković, M. (2017): Botryosphaeriaceae-prouzrokovači raka i vaskularnog sušenja četinarskog drveća i žbunja u urbanim sredinama u Srbiji. Topola 199-200: 55-75.

102.Zlatković, M. (2018): Botryosphaeriaceae: prouzrokovači rupičavosti i sušenja lišća, raka i vaskularnog sušenja lišćara u urbanim područjima u Srbiji. Topola 201-202: 167-178.

103.Zlatković, M., Keča, N., Wingfield, M.J., Jami, F., Slippers, B. (2016): Botryosphaeriaceae associated with the die-back of ornamental trees in Serbia, Antonie van Leeuwenhoek, International Journal of General and Molecular Microbiology 109: 543-564.

104.Zlatković, M., Wingfield, M.J., Jami, F., Slippers, B. (2019): Genetic uniformity characterizes the invasive spread of Neofusicoccum parvum and Diplodia sapinea in the Western Balkans. Forest pathology 49: e12491.

105.Zlatković, M., Tenorio-Baigorria, I., Lakatos, T., Tóth, T., Koltay, A., Pap, P., Marković, M., Orlović, S. (2020): Bacterial canker disease on Populus $\times$ euramericana caused by Lonsdalea populi in Serbia. Forests 11: 1080.

106.Zhongming, Z., Linong, L., Wangqiang, Z., Wei, L. (2021): Global Climate Litigation Report: 2020 Status Review. UNEP.

107.Zakon o klimatskim promenama („Sl. glasnik RS", br. 26/2021). 